Apidologie, 1978, 9 (3), 213-222.

\title{
BACTERIA BELONGING TO THE GENUS BACILLUS ISOLATED FROM HONEY BEES, APIS MELLIFERA, FED 2,4-D AND ANTIBIOTICS (1)
}

\author{
Martha GILLIAM
}

L.S. Department of Agriculture, Science and Education Administration, Bee Research Laborator. 2000 E. Allen Road, Tucson, Arizona 85719

and

Howard L. MORTON

U.S. Department of Agriculture, Science and Education Administration, Rangelands Weed and Brush Control

2000 E. Allen Road, Tucson, Arizona 85719

\section{SUMMARY}

The guts of 388 adult worker honey bees, Apis mellifera, from caged control colonies, from colonies fed (2.4-dichlorophenoxy) acetic acid (2,4-D), and from colonies fed a combination of oxytetracycline and fumagillin were examined over a period of 13 months for organisms of the genus Bacillus. One hundred and ten organisms belonging to 13 species were identified. Bacillus megaterium, B. subtilis, and B. pumilus were the most frequently isolated organisms and were found in bees in all three treatment groups. The antibiotics and 2,4-D reduced the number of bee guts containing Bacillus. No Bacillus organisms were isolated during the hot summer months of June-September. Thus, weather may also influence the composition of the gut microflora.

\section{INTRODUCTION}

For several years, we have been examining the intestinal microflora of honey bees, Apis mellifera, with the ultimate goal of determining the role of microorganisms in the nutrition and physiology of these insects. One aspect of this investigation has concerned the effects of antibiotics used to control bee diseases and of pesticides on the gut microflora of bees. Thus, we isolated and identified enteric bacteria (Gilliam and Morton, 1974), molds (Gilliam et al., 1974 a), and yeasts (Gilliam et

(1) Mention of a proprietary product or company name does not constitute an endorsement by the U.S. Depart ment of Agriculture. 
al., $1974 \mathrm{~b}$ ) from the guts of adult worker bees from control colonies, from colonies fed a combination of the antibiotics oxytetracycline (TM-25) and fumagillin (Fumidil B), and from colonies fed the herbicide (2,4-dichlorophenoxy) acetic acid (2,4-D). From this work, we concluded that the antibiotics depressed the growth of Enterobacteriaceae, molds, and yeasts and that 2,4-D caused a proliferation of intestinal yeasts but had little effect on the molds or Enterobacteriaceae.

Recently we reviewed the literature concerning bacteria of the genus Bacillus that have been isolated from honey bees and reporied the isolation of 14 species from the guts of foraging worker bees (GILliaM and VALENTINE, 1976). Since information about the incidence of these sporeforming rods in honey bees is scant and since we wished to assess the effects of 2,4-D and the antibiotics on these organisms, we report here the results of examination of the guts of adult worker bees from control colonies, from colonies fed 2,4-D, and from colonies fed a combination of oxytetracycline and fumagillin.

\section{MATERIAL AND METHODS}

The procedures for establishing, caging, maintaining, and feeding bee colonies were described in detail by Gilliam and Morton (1974). Two tests were conducted to obtain data throughout the year. In the first test, each of the three hives receiving a different treatment (control, herbidide-fed, and antibiotic-fed) was placed in a separate $12 \times 12 \times 9$-ft Saran mesh cagc. In the second test, nine hives were used, and the three colonies receiving the same treatment were placed in the same cage. Thus, in the two tests, bees were examined from a total of 12 colonies : four control colonies. four colonies fed 2,4$\mathrm{D}$, and four colonies fed the antibiotics.

Briefly, the procedure was to feed all colonies $1-1 \mathrm{~b}$ pollen patties (maintenance diet), which were replenished weekly. Colonies receiving the herbicide were fed the dimethylamine salt of 2,4-D at a concentration of $1000 \mathrm{ppm}$ active ingredient by weight in $60 \%$ sucrose-water solution from a jar placed directly above the frames containing brood (MORTON and MOFFETT, 1972). The mixture of herbicide and syrup was replenished twice a week. Colonies fed antibiotics were given the maintenance diet plus $0.5 \mathrm{~g} \mathrm{TM}-25$ and $0.5 \mathrm{~g}$ Fumidil B in addition to $60 \%$ sucrose-water solution. Control colonies received the maintenance diet and $60 \%$ sucrose-water solution. Fresh water was available to all colonies.

In the first test, three adult worker bees from each colony were examined weekly. The intestinal tracts (esophagus to rectum) were aseptically removed and individually homogenized in $2.5 \mathrm{ml}$ of sterile $0.85 \% \mathrm{NaCl}$ as previously described (GILliam and PREST, 1972). A loopful of the homogenate from each bee was streaked in duplicate on trypticase soy agar (BBL) and nutrient agar (Difco) in petri dishes. All plates were incubated under aerobic conditions at $37^{\circ} \mathrm{C}$ for 14 days.

In the second test, every three weeks the intestines of two bees from each of the nine colonies were individually homogenized in $2.5 \mathrm{ml}$ of sterile thioglycollate $135 \mathrm{C}$ medium (BBL). Each homogenate was streaked in duplicate on trypticase soy agar, nutrient agar, and eugonagar $(\mathrm{BBL})$. One plate was incubated at $25^{\circ} \mathrm{C}$ and one at $37^{\circ} \mathrm{C}$ under aerobic conditions for 14 days.

All resulting bacterial colonies were stained by the Gram method and. if necessary, were restreaked on plates of the same medium used for initial isolation to obtain pure cultures. Gram-stained slides of the cultures were examined for spores. The size, shape, and location of the spores within the sporangia and the morphology of the vegetative cells were noted. Bacteria belonging to the genus Bacillus were maintained on slants of nutrient agar. They were then tested and identified according to GoRDon $e t$ al. (1973). 
In the first test, bees were sampled from July 1971 to January 1972 . In the second test, they were sampled from September 1971 to August 1972 though all the herbicide-fed colonies had died by April 1972, a control colony died in May 1972, and an antibiotic-fed colony died in June 1972 . We attribute the death of the herbicide-fed colonies to the ovicidal and larvicidal effects of 2,4-D (MORTON and MOFFETT, 1972).

\section{RESULTS AND DISCUSSION}

One hundred and twelve Bacillus organisms were isolated, and 110 belonging to 13 species were identified from the 388 bees that we examined (Table 1). We were unable to identify two isolates, one resembling $B$. alvei and the other resembling $B$. sphaericus. Since we were interested in determining the number of bee guts containing Bacillus organisms but not the total number of Bacillus cells per bee gut, more isolates were identified than are shown in the tables to estimate adequately the number of species present. Bacillus megaterium, B. subtilis, and B. pumilus were found in the bee guts most frequently. These organisms were isolated from bees in all three treatment groups.

TABL. 1. - Bacillus Isolated From Control Bees, Bees Fed 2,4-D, and Bees Fed Oxytetracycline and Fumagillin ${ }^{a}$

\begin{tabular}{l|c}
\hline \multicolumn{1}{c|}{ Organism } & $\begin{array}{c}\text { Number of bee guts } \\
\text { containing the organism }\end{array}$ \\
\hline Bacillus megaterium & 27 \\
B. subtilis & 21 \\
B. pumilus & 21 \\
B. licheniformis & 10 \\
B. circulans & 10 \\
B. alvei & 8 \\
B. coagulans & 3 \\
B. brevis & 3 \\
B. cereus & 2 \\
B. sphaericus & 2 \\
B. firmus & 1 \\
B. laterosporus & 1 \\
B. polymyxa & 1 \\
Unidentified & 2 \\
\hline
\end{tabular}

${ }^{a} 388$ bee guts examined

Table 2 gives the results of isolations in the first test. Bacillus licheniformis and $B$. subtilis were found most frequently, in 10 and eight bee guts, respectively. Fifteen of the isolates (in 14 bees) were found in control bees, nine were found in bees fed 2,4$\mathrm{D}$ and only three were found in bees fed antibiotics. Thus, in this test, the antibiotics greatly reduced the number of bee guts containing Bacillus. In fact, the three guts 
from bees fed antibiotics that contained the organisms were collected the same day. No guts of bees fed antibiotics contained Bacillus organisms four months after the start of the test.

TABL. 2. - Bacillus Isolated From Honey Bees - First Test

\begin{tabular}{|c|c|c|c|}
\hline Organism & Treatment $^{\mathrm{a}}$ & $\begin{array}{l}\text { Date } \\
\text { isolated }\end{array}$ & $\begin{array}{l}\text { Number of bee guts } \\
\text { containing the organism }\end{array}$ \\
\hline Bacillus subtilis & $\mathrm{C}$ & $10 / 12 / 71$ & 1 \\
\hline B. licheniformis & $\mathrm{C}$ & $10 / 18 / 71$ & 1 \\
\hline B. sphaericus & C & $10 / 26 / 71$ & 1 \\
\hline B. cereus & $\mathrm{C}$ & $10 / 26 / 71$ & I \\
\hline B. megaterium & $\mathrm{C}$ & $11 / 1 / 71$ & 1 \\
\hline B. megaterium $\left\{\begin{array}{l}\text { from } \\
\text { same }\end{array}\right.$ & C & $11 / 1 / 71$ & I \\
\hline B. licheniformis | bee & $\mathrm{C}$ & $11 / 1 / 71$ & 1 \\
\hline B. subtilis & $\mathrm{C}$ & $11 / 1 / 71$ & 1 \\
\hline B. subtilis & A & $11 / 1 / 71$ & 1 \\
\hline B. licheniformis & A & $11 / 1 / 71$ & 1 \\
\hline B. megaterium & A & $11 / 1 / 71$ & 1 \\
\hline B. circulans & $\mathrm{H}$ & $11 / 1 / 71$ & 1 \\
\hline B. licheniformis & $\mathrm{H}$ & $11 / 1 / 71$ & 1 \\
\hline B. licheniformis & $\mathrm{C}$ & $11 / 8 / 71$ & 1 \\
\hline B. subtilis & $\mathrm{C}$ & $11 / 15 / 71$ & 2 \\
\hline B. subtilis & $\mathrm{H}$ & $11 / 15 / 71$ & 1 \\
\hline B. circulans & $\mathrm{C}$ & $11 / 22 / 71$ & 1 \\
\hline B. brevis & $\mathrm{H}$ & $11 / 29 / 71$ & 1 \\
\hline B. subtilis & $\mathrm{C}$ & $12 / 13 / 71$ & 1 \\
\hline B. subtilis & $\mathrm{H}$ & $12 / 13 / 71$ & 1 \\
\hline B. licheniformis & $\mathrm{H}$ & $12 / 13 / 71$ & 1 \\
\hline B. licheniformis & $\mathrm{C}$ & $12 / 27 / 71$ & 1 \\
\hline B. polymyxa & $\mathrm{C}$ & $12 / 27 / 71$ & 1 \\
\hline B. licheniformis & $\mathrm{H}$ & $12 / 27 / 71$ & 3 \\
\hline
\end{tabular}

${ }^{\mathrm{a}} \mathrm{C}=$ control; $\mathrm{H}=2$, 4-D; $\mathrm{A}=$ antibiotics

The organisms isolated in the second test are shown in Table 3 . Bacillus megaterium, $B$. pumilus, and $B$. subtilis were isolated most frequently. Thirty-rine isolates (from 30 bees) of Bacillus organisms were found in control bees that were sampled for nine months, 20 (from 16 bees) were found in bees fed 2,4-D that were sampled for seven months, and 26 (from 22 bees) were found in bees fed antibiotics that were sampled for 11 months. Thus, 2, 4-D and the antibiotics reduced the number of bee guts containing Bacillus though only 94 of 388 , or $24 \%$, of the bee guts examined contained these organisms.

Of the frequently encountered organisms, $B$. licheniformis was isolated in the first test but not in the second test. Bacillus pumilus and B. alvei were found in bees in the 
TABL. 3. - Bacillus Isolated From Honey Bees - Second Test

\begin{tabular}{|c|c|c|c|c|}
\hline \multicolumn{2}{|c|}{ Organism } & Treatment" & $\begin{array}{c}\text { Date } \\
\text { isolated }\end{array}$ & $\begin{array}{l}\text { Number of bee guts } \\
\text { containing the organism }\end{array}$ \\
\hline Bacillus subtilis & & $\mathrm{C}$ & $10 / 19 / 71$ & 1 \\
\hline B. subtilis & & $\mathrm{H}$ & $10 / 19 / 71$ & 1 \\
\hline B. coagulans & & A & $10 / 19 / 71$ & 1 \\
\hline B. coagulans & $\begin{array}{l}\text { from } \\
\text { same }\end{array}$ & $\mathrm{C}$ & $11 / 9 / 71$ & 1 \\
\hline B.pumilus & bee & $\mathrm{C}$ & $11 / 9 / 71$ & 1 \\
\hline B. coagulans & & $\mathrm{C}$ & $11 / 9 / 71$ & 1 \\
\hline B. subtilis & & $\mathrm{C}$ & $11 / 9 / 71$ & 1 \\
\hline B. subtilis & & $\mathrm{H}$ & $11 / 9 / 71$ & 1 \\
\hline B. subtilis & & A & $11 / 9 / 71$ & 1 \\
\hline B. megaterium & $\begin{array}{l}\text { from } \\
\text { same }\end{array}$ & A & $11 / 9 / 71$ & 1 \\
\hline Unidentified & bee & A & $11 / 9 / 71$ & 1 \\
\hline B. firmus & $\left\{\begin{array}{l}\text { from } \\
\text { same }\end{array}\right.$ & $\mathbf{H}$ & $11 / 30 / 71$ & 1 \\
\hline B. megaterium & bee & $\mathrm{H}$ & $11 / 30 / 71$ & 1 \\
\hline B. megaterium & & $\mathrm{H}$ & $11 / 30 / 71$ & 2 \\
\hline B. megaterium & & $\mathrm{H}$ & $12 / 21 / 71$ & 1 \\
\hline B. pumilus & & A & $12 / 21 / 71$ & 1 \\
\hline B. megaterium & & $\mathrm{C}$ & $1 / 11 / 72$ & 2 \\
\hline B. brevis & & $\mathrm{C}$ & $1 / 11 / 72$ & 1 \\
\hline B. circulans & & A & $1 / 11 / 72$ & 1 \\
\hline B. megaterium & & A & $1 / 11 / 72$ & 1 \\
\hline B. sphaericus & & $\mathrm{C}$ & $2 / 1 / 72$ & 1 \\
\hline B. subtilis & & $\mathrm{C}$ & $2 / 1 / 72$ & 1 \\
\hline B. circulans & from & $\mathrm{H}$ & 2/ $1 / 72$ & 1 \\
\hline B. subtilis & same & $\mathrm{H}$ & $2 / 1 / 72$ & 1 \\
\hline B. megaterium & bee & $\mathrm{H}$ & $2 / 1 / 72$ & 1 \\
\hline B. megaterium & & $\mathrm{H}$ & $2 / 1 / 72$ & 1 \\
\hline B. pumilus & & $\mathrm{H}$ & $2 / 1 / 72$ & 2 \\
\hline B. subtilis & $\begin{array}{l}\text { from } \\
\text { same }\end{array}$ & A & $2 / 1 / 72$ & 1 \\
\hline B. megaterium & bee & A & $2 / 1 / 72$ & 1 \\
\hline B. megaterium & & $\mathrm{A}$ & $2 / 1 / 72$ & 1 \\
\hline B. megaterium & & $\mathrm{C}$ & $2 / 23 / 72$ & 2 \\
\hline B.pumilus & & $\mathrm{C}$ & $2 / 23 / 72$ & 1 \\
\hline B. pumilus & from & $\mathrm{C}$ & $2 / 23 / 72$ & 1 \\
\hline B. subtilis & same & $\mathrm{C}$ & $2 / 23 / 72$ & 1 \\
\hline B. circulans & bee & $\mathrm{C}$ & $2 / 23 / 72$ & 1 \\
\hline B. alvei & & $\mathrm{C}$ & $2 / 23 / 72$ & 2 \\
\hline B. circulans & & $\mathrm{H}$ & $2 / 23 / 72$ & 1 \\
\hline B. circulans & & $\mathrm{A}$ & $2 / 23 / 72$ & 1 \\
\hline B. brevis & from & $\mathrm{C}$ & $3 / 14 / 72$ & $i$ \\
\hline B. circulans & same & $\mathrm{C}$ & $3 / 14 / 72$ & 1 \\
\hline B. subtilis & bee & $\mathrm{C}$ & $3 / 14 / 72$ & 1 \\
\hline B. alvei & & $\mathrm{H}$ & $3 / 14 / 72$ & 3 \\
\hline
\end{tabular}




\begin{tabular}{|c|c|c|c|c|}
\hline \multicolumn{2}{|c|}{ Organism } & Treatment $^{\mathrm{a}}$ & $\begin{array}{c}\text { Date } \\
\text { isolated }\end{array}$ & $\begin{array}{l}\text { Number of bee guts } \\
\text { containing the organism }\end{array}$ \\
\hline B. alvei & $\begin{array}{l}\text { from } \\
\text { same }\end{array}$ & $\mathrm{H}$ & $3 / 14 / 72$ & 1 \\
\hline B. laterosporus & bee & $\mathrm{H}$ & $3 / 14 / 72$ & l \\
\hline Unidentified & & $\mathrm{H}$ & $3 / 14 / 72$ & 1 \\
\hline B. Inegaterium & & A & $3 / 14 / 72$ & 2 \\
\hline B. subtilis & $\begin{array}{l}\text { from } \\
\text { same }\end{array}$ & A & $3 / 14 / 72$ & 1 \\
\hline B.pumilus & bee & A & $3 / 14 / 72$ & 1 \\
\hline B. megaterium & & C & $4 / 4 / 72$ & 2 \\
\hline B. pumilus & $\begin{array}{l}\text { from } \\
\text { same }\end{array}$ & $\mathrm{C}$ & $4 / 4 / 72$ & 1 \\
\hline B. circulans & bee & $\mathrm{C}$ & 4/ 4/72 & 1 \\
\hline B. circulans & & $\mathrm{C}$ & 4/ $4 / 72$ & 1 \\
\hline B. subtilis & & $\mathrm{C}$ & $4 / 4 / 72$ & 1 \\
\hline B. cereus & $\begin{array}{l}\text { from } \\
\text { same }\end{array}$ & $\mathrm{C}$ & $4 / 4 / 72$ & 1 \\
\hline B. pumilus & bee & $\mathrm{C}$ & $4 / 4 / 72$ & 1 \\
\hline B. subtilis & & $\mathrm{A}$ & 4/ 4/72 & 1 \\
\hline B. megaterium & & $\mathrm{C}$ & $4 / 25 / 72$ & 2 \\
\hline B.pumilus & & A & $4 / 25 / 72$ & 6 \\
\hline B. pumilus & & $\mathrm{C}$ & $5 / 16 / 72$ & 2 \\
\hline B.pumilus & $\begin{array}{l}\text { from } \\
\text { same }\end{array}$ & $\mathrm{C}$ & $5 / 16 / 72$ & 1 \\
\hline B. aliei & bee & $\mathrm{C}$ & $5 / 16 / 72$ & 1 \\
\hline B. alvei & $\begin{array}{l}\text { from } \\
\text { same }\end{array}$ & $\mathrm{C}$ & $5 / 16 / 72$ & 1 \\
\hline B. megaterium & bee & C & $5 / 16 / 72$ & I \\
\hline B. megaterium & & $\mathrm{C}$ & $5 / 16 / 72$ & 2 \\
\hline B.pumilus & from & $\mathrm{A}$ & $5 / 16 / 72$ & 2 \\
\hline B. pumilus & same & A & $5 / 16 / 72$ & 1 \\
\hline B. megaterium & bee & A & $5 / 16 / 72$ & 1 \\
\hline
\end{tabular}

second test but were not isolated in the first test. All isolations of $B$. alvei and all but two of $B$. pumilus were made after the first test was terminated. Perhaps, if the first test had extended beyond January 1972, these organisms would have been isolated. However, Bacillus licheniformis was isolated from October 1971 through December 1971. Therefore, it is surprising that it was not found in bees in the second test.

Of special interest is the fact that no Bacillus organisms were isolated from bee guts during the hot summer months of June, July, August, and September. TyssET and DuRAND (1968) examined the midgut and hindgut of adult worker bees in France from October to March and reported that $29 \%$ of the microorganisms isolated 
were Gram positive. Similarly, Fedorova and Guseva (1964) concluded that intestines of adult worker bees always contain spore formers in winter. In contrast, El-Leithy and El-Sibaei (1972) examined microorganisms from the surfaces, crops, and intestines of adult worker bees in Egypt during the flowering of citrus (March to May) and of cotton (June to August) and concluded that aerobic sporeforming bacilli were the most frequently encountered organisms representing $61-83 \%$ of the flora. We also examined foraging worker bees from free-flying colonies in December (GILliam and VALENTINE, 1976) and found Bacillus organisms in all bee guts. Therefore, climate, weather, and vegetation-may influence the composition of the gut microflora.

TYSSET and DURAND (1968) reported that the low population of spore formers in the intestinal contents of bees indicated that these bacilli are there in transit since sporogenous bacteria are present in soils and are found only accidentally and in limited numbers on the floral organs of plants. Thus they postulated that bees do not have much chance of being heavily contaminated. Moreover, they thought that the high osmotic pressure and relatively low $p \mathrm{H}$ of the intestinal content of bees would also limit the population of bacilli. EL-LeItHY and El-SibaeI (1972), in contrast, postulated that the predominance of spore-forming bacilli on the surface of bees as well as in the crop and gut may indicate that bacteria normally present on flowers continuously enter the alimentary canal. They reported that conditions in the gut were favorable for these bacteria and that the source of food influences the composition of the microflora of the gut.

The bees that we used in our tests were obtained from caged colonies and thus were not foraging on flowers. Therefore, only soil, wind, and food, and water could have served as sources of inocula. In fact, as shown in Table-4, more bee guts contained organisms belonging to the genus Bacillus than contained Enterobacteriaceae (Gilliam and MORTON 1974) or molds (GILliam et al., 1974 a). Only the yeasts that appear to be indicative of stressed bees (GILliam et al., 1974 b) were found in more bee guts from colonies treated with 2,4-D and untreated colonies.

TABL. 4. - Number of Bee Guts Containing Bacteria, Yeasts, and Molds

\begin{tabular}{|c|c|c|c|}
\hline \multirow{2}{*}{ Microorganism } & \multicolumn{3}{|c|}{ Treatment group ${ }^{a}$} \\
\hline & $\mathrm{C}$ & $\mathbf{H}$ & A \\
\hline Bacillus spp. & 44 & 25 & 25 \\
\hline Enterobacteriaceae & 13 & 15 & 12 \\
\hline Yeasts & 47 & 95 & 12 \\
\hline Molds & 20 & 15 & 8 \\
\hline
\end{tabular}

${ }^{\mathrm{a}} \mathrm{C}=$ control; $\mathrm{H}=2,4-\mathrm{D} ; \mathrm{A}=$ antibiotics 
Almost all the Bacillus organisms isolated in the present study have been previously isolated from honey bees (see Gilliam and VAlentine, 1976). The exception was $B$. sphaericus which is a new record of an organism associated with honey bees. Bacillus megaterium was found most frequently in bee guts in the present study but was not isolated from foragers (GILLIAM and VALENTINE, 1976); Bacillus polymyxa was isolated most frequently from foraging bees.

Thus, differences exist in the intestinal microflora of honey bees from caged colonies and from free-flying colonies. Also, feeding 2,4-D or a combination of oxytetracycline and fumagillin to bees causes shifts in the microflora.

Received in March 1978.

\title{
ACKNOWLEDGEMENTS
}

We thank Mr. Richard MARTIN, Mr. Randall JETER, and Mrs. Dinorah DUNHAM for their excellent technical assistance.

\section{ZUSAMMENF ASSUNG}

ZUM GENUS BACILLUS GEHÖRENDE BAKTERIEN, DIE AUS MIT 2,4-D UND ANTIBIOTIKA GEFÜTTERTEN BIENEN, APIS MELLIFERA, ISOLIERT WURDEN

Der Darminhalt von 388 erwachsenen Honigbienenarbeiterinnen wurde auf sporenbildende Bakterien des Genus Bacillus untersucht. Die Bienen wurden vier Kontrollvölkern entnommen, die Pollenteig und Zuckerlösung erhieiten, von vier weiteren Völkern, die Pollenteig und in Zuckerlösung $1000 \mathrm{ppm}$ des Herbizids (2,4-Dichlorphenoxy) - essigsäure (=2,4-D), und noch von vier weiteren Völkern, die TM 25 (Oxytetrazyklin) enthaltenden Pollenteig und Fumidil B (Fumagillin) in Zuckerlösung erhielten. Alle Völker wurden in Käfigen gehalten. Für die Untersuchungen wurden das ganze Jahr hindurch Bienen entnommen. Der Darmtrakt (Speiseröhre bis Enddarm) wurde homogenisiert und auf geeigneten mikrobiologischen Medien ausgebreitet, um Bacillus zu isolieren. Es wurden 110 zum Genus Bacillus gehörende Bakterien aus den untersuchten Bienen identifiziert. Bacillus megaterium, B. subtilis und B. pumilus wurden am häufigsten bei allen drei Versuchsgruppen isoliert. Das Herbizid und die Antibiotika verminderten die Anzahl der Bienendärme, die Bacillus enthielten, und während der heissen Sommermonate von JuniSeptember wurden keine Bacillus-Organismen isoliert. Ein Vergleich dieser Ergebnisse mit unserer früher veröffentlichten Arbeit über die Mikroflora des Darms bei Sammelbienen zeigt, dass Unterschiede bestehen in der Darmmikroflora von Honigbienen aus gekäfigten und aus frei fliegenden Völkern. Eine Fütterung der Bienenvölker mit 2,4-D oder Kombination von Oxytetrazyklin und Fumagillin verursacht Veränderungen in der Darmmikroflora der erwachsenen Arbeiterinnen. Zusätzlich mögen Klima, Wetter und Vegetation die Zusammensetzung der Mikroflora im Darm beeinflussen.

\section{RÉSUMÉ}

\author{
BACTÉRIES DU GENRE BACILLUS ISOLÉES A PARTIR D'ABEILLES, \\ APIS MELLIFERA, APRÈS ADMINISTRATION DE 2,4-D ET D'ANTIBIOTIQUES
}

On a examiné le contenu intestinal de 388 ouvrières adultes du point de vue des bactéries appartenant au genre Bacillus. Les abeilles provenaient de 4 colonies témoins qui recevaient de la pâte de pollen et du 
sirop: de 4 autres colonies qui recevaient de la pâte de pollen et du sirop renfermant 1000 ppm de l"herbicide acide 2,4-dichlorophenoxyacétique (2,4-D); et de 4 autres colonies qui recevaient de la pâte de pollen renfermant du TM-25 (oxytétracycline) et du sirop additionné de Fumidil B (fumagilline). Toutes les colonies étaient maintenues en cages.

Les abeilles étaient prélevées pour analyses tout au long de l'année. Le tractus intestinal (de l'œsophage au rectum) était homogénéisé et étalé sur un milieu microbiologique approprie pour isoler Bacillus. A partir des abeilles examinées on a pu identifier 111 bactéries du genre Bacillus. Dans les 3 groupes $B a$ cillus megaterium, $B$. subtilis et $B$. pumilus furent les plus fréquents. L herbicide et les antibiotiques ont réduit le nombre d"intestins d'abeilles renfermant Bacillus et aucun Bacillus n'a pu être isolé durant les mois chauds de juin à septembre. Si l'on compare ces résultats avec notre travail précédemment publiẻ sur la microflore intestinale des abeilles butineuses. on s'aperçoit que des différences existent entre la microflore intestinale des abeilles encagées et celle des abeilles volant librement. L'administration de 2,4-D ou d'une association d'oxytétracycline et de fumagilline provoque des changements dans la microflore intestinale des ouvrières adultes. En outre le climat, le temps et la végétation peuvent influencer sa composition.

\section{REFERENCES}

El-Leithy, M. A., El-Sibaei, K. B., 1972. - External and internal microflora of the honey bees (Apis mellifera L.). Egvpt. J. Microbiol., 7, 79-87.

Fedorova, G. N., Guseva, N. V., 1964. - ISpore-forming microorganisms of the intestines of adult honey bees.]. Leningrad. Vet. Inst., 26, 94-100.

Gilliam, M.. Morton, H. L.. 1974. - Enterobacteriaceae isolated from honey bees, Apis mellifera, treated with 2,4-D and antibiotics. J. Invertebr. Pathol., 23, 42-45.

Gilliam, M.. PRest, D. B.. 1972. - Fungi isolated from the intestinal contents of foraging worker honey bees, Apis mellifera. J. Invertebr. Pathol., 20, 101-103.

Gilliam, M.. Valentine D. K., 1976. - Bacteria isolated from the intestinal contents of foraging worker honey bees, Apis mellifera: the genus Bacillus. J. Invertebr. Pathol., 28, 275-276.

Gilliam, M., Prest, D. B., Morton, H. L., 1974 a. - Fungi isolated from honey bees, Apis mellifera, fed 2,4-D and antibiotics. J. Invertebr. Pathol., 24, 213-217.

Gilliam, M., Wickerham, L. J., Morton, H. L., Martin, R. D., 1974 b. - Yeasts isolated from honey bees, Apis mellifera, fed 2,4-D and antibiotics. J. Invertebr. Pathol., 24, 349-356.

Gordon, R. E., Haynes, W. C., Hor-NAY PAng, C., 1973. - The genus Bacillus. USDA Hand-book, 427, $1-283$.

Morton, H. L.. Moffett, J. O., 1972. - Ovicidal and larvicidal effects of certain herbicides on honey bees. Environ. Entomol, 1, 611-614.

Tesset, C.. Durand, C.. 1968. - Contribution à l'étude du microbisme intestinal des abeilles butineuses saines (Apis mellifica L.) : dénombrement et étude des groupements constitutifs (premier mémoire). Bull. Apicole, 11, 107-118. 